\title{
Implementing Article 45 (Transfer of Sentenced Persons) of the UN Convention against Corruption in Africa: prospects and challenges
}

\author{
By Jamil Ddamulira Mujuzi*
}

\begin{abstract}
Article 45 of the United Nations Convention against Corruption empowers states parties to enter into bilateral or multilateral agreements or arrangements on the transfer of offenders convicted of offences in one country to serve their sentences in another country. Many African countries have ratified the Convention against Corruption. This article discusses the prospects for the implementation of Article 45 and the challenges likely to be encountered in its implementation. The author deals with the following issues: a brief comparison between the African Union Convention on Preventing and Combating Corruption and the UN Convention against Corruption; the available options for African countries to implement Article 45; the role of the courts in the transfer of offenders; the consent of the offender to the transfer; the issue of human rights in the context of the transfer; the sentences that could be imposed and whether there should be continued enforcement or conversion thereof in the case of a transfer, the people subject to the transfer and the costs of the transfer.
\end{abstract}

$* * *$

* Senior Lecturer, Faculty of Law, University of the Western Cape (UWC) and Research Fellow, Community Law Center, UWC. LLD (UWC); LLM (University of Pretoria); LLM (University of the Free State); LLB (Makerere University). I am indebted to Prof. R Koen of UWC for directing me to some of the sources used in this article and to Prof. Leeman and the anonymous referees for their comments. This work is based on the research supported partly by the National Research Foundation of South Africa (Grant specific unique reference number (UID) 86004).The author acknowledges that opinions, findings and conclusions or recommendations expressed in this paper are those of the author and that the NRF accepts no liability whatsoever in this regard. The author presented this paper at the $2^{\text {nd }}$ Crime, Justice and Social Democracy International Conference, Queensland University of Technology, Brisbane, Australia, 8 - 11 July 2013. I am grateful to UWC and to the NRF for making it possible for me to attend this conference. Email: djmujuzi@gmail.com. 


\section{Introduction}

The United Nations Convention against Corruption (the Convention) has been ratified or acceded to by several African countries. ${ }^{1}$ Article 45 of the Convention provides that:

States Parties may consider entering into bilateral or multilateral agreements or arrangements on the transfer to their territory of persons sentenced to imprisonment or other forms of deprivation of liberty for offences established in accordance with this Convention in order that they may complete their sentences there.

Corruption is a serious problem in many African countries ${ }^{2}$ and some African countries also appear to be serious about fighting corruption. This can be gathered from the efforts being made by these countries. Apart from ratifying the UN Convention against Corruption and the African Convention on Preventing and Combating Corruption, African countries have taken measures at the domestic level to combat corruption. These have included the establishment of an Anti-Corruption Committee in Kenya, ${ }^{3}$ the Anti-Corruption Commission in Zambia, ${ }^{4}$ the Independent Commission against Corruption in Mauritius, ${ }^{5}$ the Directorate of Corruption and Economic Crimes in Botswana, ${ }^{6}$ the Ethic and Anti-Corruption Commission in the Democratic Republic of Congo, ${ }^{7}$ the anti-corruption plan in Benin, ${ }^{8}$ the Anti-Corruption Commission in Ethiopia, ${ }^{9}$ the Superior State Control Authority in Burkina Faso, ${ }^{10}$ the National

1 United Nations Convention against Corruption, Doc. A/58/422. Entered into force 14 December 2005. As at the time of writing the following African countries were states parties to this convention: Algeria; Angola; Benin; Botswana; Burkina Faso; Burundi; Cameroon; Cape Verde; Central African Republic; Comoros; Congo; Cote d'lvoire; Democratic Republic of Congo; Djibouti; Egypt; Ethiopia; Gabon; Ghana; Guinea (signed 2005 not yet ratified); Guinea Bissau; Kenya; Lesotho; Liberia; Libya; Madagascar; Malawi; Mali; Mauritania; Mauritius; Morocco; Mozambique; Namibia; Niger; Nigeria; Rwanda; Sao Tome and Principe; Senegal; Seychelles; Sierra Leone; South Africa; Sudan (signed in 2005, not yet ratified); Swaziland; Togo; Tunisia; Uganda; Tanzania; Zambia and Zimbabwe.

2 See reports by Transparency International.

3 See African Commission on Human and Peoples' Rights, B v Kenya, Communication 283/03, 04 June 2004, para 2.

4 African Commission on Human and Peoples' Rights, Report on the Promotional Mission to the Republic of Zambia (2008), paras 153 - 162.

5 African Commission on Human and Peoples' Rights, Report on the Promotional Mission to Mauritius (2006), para 52.

6 African Commission on Human and Peoples' Rights, Report on the Promotional Mission to the Republic of Botswana (2005), p. 34.

7 Initial Report of the Democratic Republic of Congo to the African Commission on Human and Peoples' Rights (2002), p. 16.

8 Benin's consolidated report to the African Commission on Human and Peoples' Rights (2008) pg 2.

9 Combined report (initial to fourth) of the Federal Democratic Republic of Ethiopia to the African Commission on Human and Peoples' Rights, p. 27.

10 Periodic Report of Burkina Faso to the African Commission on Human and Peoples' Rights (2010), p. 12. 
Anti-Corruption Commission in Cameroon, ${ }^{11}$ the 'setting up of a Ministry to specifically deal with corruption' in Zimbabwe, ${ }^{12}$ empowering the ombudsman to investigate corruption in the Seychelles, ${ }^{13}$ the enactment of legislation on corruption in different countries, ${ }^{14}$ and the African Commission's recommendations to some African countries, such as Cameroon, to take measures to eradicate corruption. ${ }^{15}$ One of the measures aimed at effectively implementing the Convention against Corruption is for state parties to assist or work with one another to ensure that those suspected of committing offences under the Convention do not evade justice or do not continue to enjoy the proceeds of their criminal activities just because they are residing or living in foreign countries. ${ }^{16}$ The transfer of offenders between countries is one of the measures of international co-operation for states parties to the Convention. The purpose of this article is to highlight the prospects and challenges that are likely to facilitate or to be confronted in the implementation of Article 45 of the Convention against Corruption. This article is based on the legislation and agreements on the transfer of offenders in Africa. It should be noted at the outset that although there is an avalanche of literature on the Convention against Corruption, ${ }^{17}$ the author is not aware of any article or book in which Article 45 has been examined in detail. ${ }^{18}$ Most importantly the author is not aware of any article or book that has discussed the prospects and challenges of implementing Article 45 in Africa.

11 Second periodic report of Cameroon to the African Commission on Human and Peoples' Rights p. 10.

12 Zimbabwe's combined $7^{\text {th }}-10^{\text {th }}$ periodic reports to the African Commission on Human and Peoples' Rights (2006), p. 47.

13 African Commission on Human and Peoples' Rights, Report on the Promotional Mission to the Republic of Seychelles (2004), p 17.

14 Seventh periodic report of Rwanda to the African Commission on Human and Peoples' Rights 1999 - 2002, p. 28. Legislation has been enacted in Uganda, Lesotho, and South Africa which criminalise corruption.

15 Concluding Observations and Recommendations on the Periodic Report of the Republic of Cameroon, 11 - 25 May 2005, para 20.

16 See Chapter IV.

17 It is not possible for the author to survey all the publications that are available on the UN Convention against Corruption.

18 Colin Nicholls, Timothy Daniel, Alan Bacarese, John Hatchard, Corruption and Misuse of Public Office, Oxford 2011, p. 434, para 12.92: the authors reproduce Article 45 without discussing it. They also mention the Council of Europe's Convention on the Transfer of Sentenced Persons and the Scheme for the Transfer of Convicted Offenders within the Commonwealth. David Chaikin and J.C. Sharman, Corruption and Money Laundering: A Symbiotic Relationship, New York 2009, pp. 38 48, 121 - 123, and 191 - 197: the authors deal with various provisions of the UN Convention against Corruption but do not discuss article 45.Philippa Webb, The United Nations Convention Against Corruption GlobalAchievement or Missed Opportunity?, Journal of International Economic Law 8 (1) (2005), pp. 191 - 229: the author deals comprehensively with the drafting history of the Convention, focusing on the following four areas (excluding article 45), asset recovery, private sector corruption, political corruption, and monitoring. Antonio Argandoña, The United Nations Convention Against Corruption and its Impact on International Companies,Journal of Business Ethics 74 (2007), pp. 481-496 does not discuss Article 45 at all although the drafting history of the Convention is dealt with. 
This article deals with the following issues: comparing the relevant provisions of the UN Convention against Corruption with the African Union Convention on Preventing and Combating Corruption; the drafting history of Article 45 of the UN Convention against Corruption; the available options to implement Article 45 of the UN Convention against Corruption in Africa; the role of the courts in the transfer of offenders; consent of the offender before the transfer; human rights in the context of the transfer of offenders; the nature of the sentences that could be imposed in terms of the UN Convention against Corruption and how those sentences could be administered; people subject to transfer; The costs of the transfer; and the conclusion. It is imperative to compare some of the provisions of the African Union Convention on Preventing and Combating Corruption with UN Convention against Corruption. The purpose of this comparison is to highlight the importance of Article 45 of the UN Convention against Corruption in Africa.

\section{Comparing the relevant provisions of the UN Convention against Corruption with the African Union Convention on Preventing and Combating Corruption}

The African Union Convention on Preventing and Combating Corruption ${ }^{19}$ (the African Union Convention), which came into force on 5 August 2006, is one of the anti-corruption regional instruments specifically referred to in the preamble to the UN Convention against Corruption. In other words, the African Union had a treaty in place on corruption before the UN adopted one. The obvious questions that arise are: why did African countries participate in the drafting process of, and why have some ratified, the UN Convention against Corruption? The answer is as obvious as the questions: the African Union Convention is a regional instrument whereas the UN Convention is an international one. But most importantly, the UN Convention against Corruption is more comprehensive than the African Union Convention. The UN Convention has a total of 71 Articles compared to the 28 Articles that make up the African Union Convention. It is not possible in this article to compare all the Articles of the two treaties. The author will briefly compare those provisions that relate to international co-operation and mutual legal assistance as they are relevant to the present discussion. Although both the UN Convention and the African Union Convention have relevant provisions on international cooperation and mutual legal assistance, ${ }^{20}$ the African Union Convention provisions are brief compared to those of the UN Convention. Of great importance is the fact that the African Union Convention is silent on the issue of the transfer of individuals convicted of corruption to serve their sentences in a country other than the sentencing country. However, there are provisions in the African Union Convention that could be interpreted broadly to allow the transfer of offenders between countries. The first provision is Article 15(6) which provides:

Where a State Party in whose territory any person...convicted of offences is present and has refused to extradite that person on the basis that it has jurisdiction over of-

19 Adopted by the 2nd Ordinary Session of the Assembly of the African Union, Maputo, 11 July 2003.

20 Articles $18-19$ of the African Union Convention and $43-50$ of the UN Convention. 
fences, the Requested State Party shall be obliged to submit the case without undue delay to its competent authorities for the purpose of prosecution, unless otherwise agreed with the Requesting State Party, and shall report the final outcome to the Requesting State Party.

In terms of Article 15(6) the requested state may refuse to extradite 'any person' whether that person is a citizen of the requested state or the requesting state, on the basis that it has jurisdiction over the offence. If the extradition is refused, the requested state has to submit the case to its competent authorities, for example, the office of the prosecutor, for the purpose of prosecution 'unless otherwise agreed with the Requesting State Party.' It is the author's submission that the phrase 'unless otherwise agreed with the Requesting State Party' could be interpreted as empowering the requested state to enforce a sentence imposed by the courts in the requesting state. This would require the existence of a treaty or legislative mechanism that enables the person in question to serve his sentence in the requested state. However, it is important to bear in mind that in this case the offender is present in the state that will be enforcing the sentence and there is no need to have him transferred. What is being transferred is the sentence that has been imposed in the requesting state. The effect of the transfer would be that the offender would have to be arrested to start to serve the sentence imposed by the requesting state. ${ }^{21}$ Article $18(5)$ of the African Union Convention could also be interpreted to allow the enforcement of a sentence imposed by one country in another country. It provides that ' $[t]$ he provisions of this Article shall not affect the obligations under any other bilateral or multilateral treaty which governs, in whole or in part, mutual legal assistance in criminal matters.' This could be interpreted to mean that if states parties to the African Union Convention are also states parties to a bilateral or multilateral treaty on the transfer of offenders, they could invoke such a treaty as being one of the measures to fulfil one of their obligations in terms of Article 18(1), viz, to 'punish acts of corruption and related offences. ${ }^{22}$ It should be recalled that one of the objectives of the African Union Convention is to '[p]romote, facilitate and regulate cooperation among the State Parties to ensure the effectiveness of measures and actions to prevent, detect, punish and eradicate corruption and related offences in Africa.' One of the ways in which a person could effectively be punished for corruption is to ensure that he is transferred to serve his sentence in his country of nationality, or in cases where he has not been extradited from his country of nationality to serve his sentence in another country, his country of nationality enforces the sentence imposed by another country. It should

21 For example, this is possible in terms of article 4 of the Council Framework Decision 2008/909/JHA of 27 November 2008 on the application of the principle of mutual recognition to judgments in criminal matters imposing custodial sentences or measures involving deprivation of liberty for the purpose of their enforcement in the European Union (OJ L 327, 5.12.2008, p. 27).

22 Article 18(1) of the African Union Convention provides that 'In accordance with their domestic laws and applicable treaties, State Parties shall provide each other with the greatest possible technical cooperation and assistance in dealing immediately with requests from authorities that are empowered by virtue of their national laws to prevent, detect, investigate and punish acts of corruption and related offences.'. 
be emphasised that the African Union Convention does not include a provision that expressly empowers states parties to put in place measures aimed at transferring persons who have been sentenced to custodial or non-custodial sentences in one country to serve such sentences in another country. It is against that background that it is critical for one to examine in detail Article 45 of the UN Convention against Corruption and how it is likely to be implemented in Africa.

\section{The drafting history of Article 45}

The drafting history of Article 45 shows that the delegates did not spend much time debating it. This could be attributed to the fact that by the time the Convention against Corruption was debated the need to transfer offenders to their countries of nationality had been appreciated at the international, regional, ${ }^{23}$ and national levels. The drafting history of Article 45 shows that at the Informal Preparatory Meeting of the Ad Hoc Committee for the Negotiation of a Convention against Corruption which took place in Buenos Aires from 4 - 7 December 2001, three countries - Austria, The Netherlands and Colombia - submitted proposals which were based on Article 17 of the United Nations Convention against Transnational Organised Crime, ${ }^{24}$ and the Ad Hoc Committee consolidated these proposals and drafted the rolling text which was discussed at Vienna at the first session (as Article 52) (5) $^{25}$ and which provided:

States Parties may consider entering into bilateral or multilateral agreements or arrangements on the transfer to their territory of persons sentenced to imprisonment or other forms of deprivation of liberty for offences covered by this Convention, in order that they may complete their sentences there. ${ }^{26}$

The drafting history of Article 45 shows that ' $[\mathrm{t}]$ here were no comments on this article during the first reading of the draft text, at the second session of the Ad Hoc Committee. ${ }^{27}$ It should be recalled that Article 17 of the United Nations Convention against Transnational Organised Crime provides for the transfer of offenders convicted of 'offences covered by' this Convention. The consolidated proposal based on the submissions by Austria, The Netherlands and Colombia had reproduced verbatim Article 17 of the United Nations Convention and Transnational Organised Crime.Because of the fact that there were no comments from any delegation

23 See generally M. Abdul-Aziz, International Perspective on Transfer of Prisoners and Execution of Foreign Penal Judgments, in: M. Cherif Bassiouni (ed:) International Criminal Law: Multilateral and Bilateral Enforcement Mechanisms: Volume II. Leiden (2008); p.529.

24 Article 17 of the United Nation Convention provides: "States Parties may consider entering into bilateral or multilateral agreements or arrangements on the transfer to their territory of persons sentenced to imprisonment or other forms of deprivation of liberty for offences covered by this Convention, in order that they may complete their sentences there.'.

25 The first session took place at Vienna from 21 January - 1 February 2002.

26 United Nations Office on Drugs and Crime, Travaux Préparatoires of the negotiations for the elaboration of the United Nations Convention against Corruption (2010), p. 363.

27 Note 28, p. 363. 
on the draft Article 52, the Consistence Group, which had been established by the Ad Hoc Committee 'to ensure, inter alia, consistency within the text of the draft convention' had to decide whether to use the phrase "offences covered by this Convention" or "offences established in accordance with this Convention.'28 The question to be answered was whether the choice between the two phrases "was a substantive matter or a matter pertaining to consistency. ${ }^{29}$ After deciding that it was a matter of consistency, '[t] he consistency group then decided to recommend replacing the phrase "offences covered by this Convention" with the phrase "offences established in accordance with this Convention" in article 52 of the draft convention. ${ }^{30}$ At its fifth session which was held in Vienna from 10 - 21 March 2003, 'the Ad Hoc Committee provisionally approved Article 52 of the draft convention. ${ }^{31}$ At its seventh session which took place in Vienna from 29 September - 1 October 2003, 'the Ad Hoc Committee considered, finalized and approved the article...that was submitted to the General Assembly for adoption. ${ }^{32}$ The General Assembly approved Article 52 as presented to it by the Ad Hoc Committee and it would later become Article 45 of the Convention. ${ }^{33}$ There is not much more to say about the drafting history of Article 45 except that no African country is reported to have contributed to its drafting at any stage, even though African countries, such as, South Africa, Egypt, Zambia, Algeria, Libya, Botswana, Nigeria, Uganda, Cameroon, Burkina Faso, Senegal, Morocco, the Gambia, and Benin, submitted proposals on various draft provisions of the Convention. ${ }^{34}$ It is not clear why African countries did not comment or submit proposals on Article 45. Could this be attributed to the fact that at the time the Convention was drafted, and indeed at the time of writing this article, Africa did not have a regional multilateral treaty on the transfer of offenders? One has to recall that the three countries that submitted the proposals that formed the basis of Article 45 come from regions which had multilateral prisoner transfer agreements at the time the Convention against Corruption was being adopted. However, the strength of this argument weakens in the light of the fact

28 Note 28 , p. 363.

29 Ibid.

30 Ibid.

31 Ibid.

32 Ibid.

33 Note 28 , pg $363-364$.

34 Note 28, pp. 22, 32, 106, 107, 108, 132, 157, 179, 196, 302, 320, and 401 (South Africa's contribution); 28, 29, 88, 92, 166, 205, 208, 252, 268, 269, 270, 281, 282, 288, 292, 297, 312, 324, 331, 350, $353,378,560,563,564,566,570,620,627$, and 632 (for Egypt's contribution); 33, 142, 412, 418, 424, 435, 504, and 518 (for Zambia's contribution); 35, 36, 38, 56, 62, 72, 87, 88, 97, 99, 142, 192, 197, 198, 244, 324, 412, 430, 440, 481, 482, 484, 487, 502, 505, 507, 608, and 609 (for Algeria's contribution); 17, 37, 56, 71, 100, 132, 189, 268, 378, 509, and 563 (for Libya's contribution); 43, $89,179,240$, and 244 (for Botswana's contribution); 92, 205, and 208 (for Nigeria's contribution); 205, 208, and 592 (for Uganda's contribution); 93, 179, 240, 244, and 341 (for Cameroon's contribution); 93 (for Burkina Faso's contribution); 93 (for Senegal's contribution); 111, 271, 293 (for Morocco's contribution); 315 (for The Gambia's contribution); 92, 93, and 391 (for Benin's contribution). 
that some of the African countries were members of the Commonwealth who knew, or ought to have known, of the Scheme for the Transfer of Convicted Offenders within the Commonwealth and some had national legislation on the transfer of offenders. It is also not clear why Cameroon, which was one of the countries that had proposed the inclusion of a provision in the treaty that would address issues, such as, extradition, transfer of offenders, mutual legal assistance, and transfer of criminal proceedings, did not comment on draft Article 52. ${ }^{35} \mathrm{We}$ now turn our attention to the available options, all or some of which could be adopted by African countries to put Article 45 into effect.

\section{Available options to implement Article 45}

It is critical to deal with the options available to African countries in implementing Article 45. Article 45 provides that states parties 'may consider entering into bilateral or multilateral agreements or arrangements' aimed at the transfer of offenders. There are four options, which are not mutually exclusive, that could be adopted by African countries to put in place a regime for the transfer of offenders. The first option is to enact prisoner transfer legislation to regulate the transfer of these offenders. As will be shown below, this approach has been taken by some African countries, such as, Namibia, Mauritius, Zimbabwe, Nigeria, Ghana, Uganda, Swaziland, and Tanzania. ${ }^{36}$ In such a case, the transfer of offenders could be founded on an arrangement made on the basis of the legislation in question. ${ }^{37}$ The existence of national legislation is critical, especially to facilitate the establishment of bilateral prisoner transfer agreements. ${ }^{38}$ This has been the case, for example, between Nigeria and the United Kingdom. However, the fact that there is no such legislation does not mean that African countries cannot enter into bilateral arrangements or treaties to transfer offenders. Rwanda and Uganda, for

35 Cameroon, Mexico, The Netherlands and Thailand proposed that the treaty should include a provision that combined all aspects of international co-operation in its execution. See note 28, pg 341.

36 Other countries such as the United Kingdom, Canada, Hong Kong, the USA and Australia also have national legislation on the transfer of offenders.

37 In Canada an offender can be transferred to and from Canada even if there is no bilateral or multilateral treaty on transfer. Section 31 of the Canadian International Transfer of Offenders Act, S.C.2004, c. 21 provides that '[i]f no treaty is in force between Canada and a foreign entity on the transfer of offenders, the Minister of Foreign Affairs may, with the consent of the Minister, enter into an administrative arrangement with the foreign entity for the transfer of an offender in accordance with this Act.'.

38 Before the UK could sign a prisoner transfer agreement with Nigeria, UK politicians wanted to make sure that the legislation governing the transfer of offenders facilitated the compulsory transfer of offenders. The Secretary of State for Justice, Mr Blunt, informed the House of Commons: '[d]uring the Prime Minister's visit to Nigeria in July 2011, he and President Goodluck Jonathan pledged that they would work to provide a compulsory mechanism for nationals from both countries to be transferred home to serve out their sentences. The Bill to amend the relevant domestic Nigerian legislation to enable the negotiation of a compulsory PTA is now awaiting its final reading in the Nigerian Senate.' See House of Commons Hansard text of 17 January 2012, Column 703W. 
example, entered into prisoner transfer agreements with the UK although at the time none had prisoner transfer legislation. ${ }^{39}$

The second option available to African countries is to enter into bilateral prisoner transfer agreements. This means that one African country will sign a prisoner transfer agreement with another African country or another country outside Africa to regulate the circumstances under which offenders could be transferred. Some African countries have signed memorandums on the transfer of offenders between themselves, such as, Zambia and Mozambique, ${ }^{40}$ Ghana and Nigeria, ${ }^{41}$ Tanzania and Mauritius, ${ }^{42}$ and Uganda and Mauritius. ${ }^{43}$ African countries have also signed bilateral prisoner transfer agreements with some countries outside Africa. For example, the UK has signed prisoner transfer agreements with countries, such as, Uganda, ${ }^{44}$ Egypt,${ }^{45}$ Morocco, ${ }^{46}$ Rwanda, ${ }^{47}$ Libya $^{48}$ and Ghana. ${ }^{49}$

The third approach is to ratify multinational treaties on prisoner transfer. These are the Council of Europe's Convention on the Transfer of Sentenced Persons ${ }^{50}$ and the Inter-Amer-

39 The Ugandan prisoner transfer legislation was promulgated in 2012 and Rwanda is yet to enact one. For a detailed discussion of the process that was followed to enact the Ugandan legislation, see $J D$ Mujuzi, The Ugandan Transfer of Convicted Offenders Act, 2012 : A commentary, African Human Rights Law Journal 59912 (2012), pp. 599 - 622.

40 See 'Zambia and Mozambique sign MoU on the transfer of convicted persons', 26 July 2011, Lusaka Times,http://www.lusakatimes.com/2011/07/26/zambia-mozambique-sign-mou-transfer-convicted -persons/ (last accessed on 23 November 2013).

41 See 'Ghana, Nigeria to exchange prisoners', 12 January 2010, Modern Ghana News,http://www.m odernghana.com/print/258677/1/ghana-nigeria-to-exchange-prisoners.html (last accessed on 23 November 2013).

42 See Agreement between the Government of the United Republic of Tanzania and the Government of the Republic of Mauritius on the Transfer of Convicted Offenders, First Schedule to the Transfer of Prisoners (Republic of Tanzania) Regulations 2008, GN No.45 of 2008.

43 See http://www.gov.mu/portal/sites/mfamission/addisababa/news.htm (last accessed on 23 November 2013).

44 See Agreement between the Government of the United Kingdom of Great Britain and Northern Ireland and the Republic of Uganda on the Transfer of Convicted Persons (2 June 2009).

45 Agreement between the Government of the United Kingdom of Great Britain and Northern Ireland and the Government of the Arab Republic of Egypt the Transfer of Prisoners (29 November 1993).

46 Agreement between the Government of the United Kingdom of Great Britain and Northern Ireland and the Government of the Kingdom of Morocco on the Transfer of Convicted Offenders (21 February 2002).

47 Agreement between the Government of the United Kingdom of Great Britain and Northern Ireland and the Government of the Republic of Rwanda on the Transfer of Sentenced Persons (11 February 2010).

48 Treaty between the Government of the United Kingdom of Great Britain and Northern Ireland and the Great Socialist People's Libyan Arab Jamahiriya on the Transfer of Prisoners (17 November 2008).

49 Agreement between the Government of the United Kingdom of Great Britain and Northern Ireland and the Government of the Republic of Ghana concerning the Transfer of Prisoners (17 July 2008).

50 European Treaty Series, No.112. 
ican Convention on Serving Criminal Sentences Abroad. ${ }^{51}$ Although these are regional instruments, they are open for ratification by countries outside those regions. In fact, the former was ratified by many countries outside Europe, including Bahamas, Bolivia, Ecuador, Israel, Japan, Korea, Mauritius, Mexico, Panama, and the United States of America, ${ }^{52}$ and the latter by countries outside Latin America, such as, Saudi Arabia and Czech Republic. ${ }^{53}$ The drafting history of the Council of Europe's Convention on the Transfer of Sentenced Persons indicates:

Unlike other conventions on international cooperation in criminal matters prepared within the framework of the Council of Europe, the Convention on the Transfer of Sentenced Persons does not carry the 'word' European in its title. This reflects the draftmen's opinion that the instrument should be open also to like-minded democratic states outside Europe. Two states - Canada and the United States of America, were, in fact, represented on the Select Committee by observers and actively associated with the elaboration of the text. ${ }^{54}$

The last option is to ratify the Scheme for the Transfer of Convicted Offenders within the Commonwealth. This Scheme has been ratified by countries, such as, the UK, Malawi and Nigeria. ${ }^{55}$ The only challenge of the Scheme is that it is only open to countries within the Commonwealth, and this excludes many African countries. ${ }^{56}$

As mentioned earlier, all these four options are not mutually exclusive. In fact the starting point would be for the enactment of national legislation to regulate the transfer of offenders. The absence of national legislation on the transfer of offenders could make a transfer impos-

51 OAS, Treaty Series, No.76.

52 See http://www.oas.org/juridico/english/sigs/a-57.html (last accessed on 23 November 2013).

53 See http://conventions.coe.int/Treaty/Commun/ChercheSig.asp? $\mathrm{NT}=112 \& \mathrm{CM}=8 \& \mathrm{DF}=\& \mathrm{CL}=\mathrm{EN}$ $\mathrm{G}$ (last accessed on 23 November 2013).

54 Explanatory Report on the Convention on the Transfer of Sentenced Persons, para 11. Canada and the USA have also ratified this treaty and courts in both countries have held that it is enforceable. In Canada (Minister of Citizenship \& Immigration) v. Li 2009 CarswellNat 598, 2009 FCA 85, 388 N.R. 169, 80 Imm. L.R. (3 d) 161, 308 D.L.R. (4th) 314, 188 C.R.R. (2 d) 71, [2010] 2 F.C.R. 433, para 43, the Federal Court of Appeal held that by ratifying that Council of Europe's Convention on the Transfer of Sentenced Persons, Canada undertook 'international obligations...to cooperate in the international enforcement of criminal law.' Several courts in the USA have held that although the Convention on the Transfer of Sentenced Persons is enforceable in the USA, it does not give an offender the right to be transferred. See for example, David F. Bagguley v. George W. Bush, President of the United States 953 F.2 d 660, 293 U.S.App.D.C. 264, 663, 267; Bradley N. Hart v. Pete Wilson; et al 1996 WL 371430 (N.D.Cal.) 2; United States of America, ex rel. Christopher Rickard v. Jerry Sternes, Warden; and Donald Snyder, Director of the Illinois Department of Corrections 149 F.Supp. $2 \mathrm{~d} 437,451$.

55 See House of Commons Hansard text of 23 January 2012: Column 92W.

56 However, there is nothing that prevents these countries from becoming part of the Commonwealth. Some countries, such as, Rwanda, Cameroon and Mozambique, were not previously part of the Commonwealth but they applied and were admitted to be part thereof. 
sible.$^{57}$ For example, the UK had signed a prisoner transfer agreement with Jamaica but the lack of national legislation in Jamaica implementing that agreement made it impossible for the UK to transfer offenders to that country. ${ }^{58}$ It is also important that the national legislation in question does not conflict with the bilateral agreement on the transfer of offenders otherwise it would be difficult for the transfer to take place. For example, although the bilateral agreement between the UK and Ghana on the transfer of offenders provides that people with close ties to Ghana, who are not Ghanaian citizens, could be transferred to Ghana, the Ghanaian national legislation provides that in order for an offender to be transferred he has to be a citizen of Ghana. ${ }^{59}$ This means that there is a tension between the transfer agreement and the national legislation, and unless it is resolved it could be an obstacle to the transfer of some offenders.

\section{Role of the courts in a transfer}

One issue that most transfer legislation or bilateral arrangements in Africa is silent about is the role of the courts in the transfer of the offenders. With the exception of the Tanzanian legislation, ${ }^{60}$ pieces of legislation are silent on the issue of the role of the courts in the transfer arrangements. Judicial oversight is critical, especially for three reasons. The first reason is to ensure that an offender is not transferred to a country where there is a real or substantial risk that his rights would be violated. An offender should have an opportunity to challenge his transfer if he has reason to believe that his rights would be violated in the enforcement state should the transfer go ahead. This is especially important in cases where the offender's consent is not needed for his transfer. The second reason for the need for judicial oversight is to ensure that the right people are transferred - that is, those who have been convicted of offences. Since the transfer of offenders is mostly effected by officers from departments or ministries located within the executive arm of government, there is a danger that political considerations could prevail over the rights of the people to be transferred. In Malawi, for example, there was an unsuccessful attempt by a prosecutor to transfer a suspect to Tanzania in terms of the prisoner transfer legislation although he had not been convicted of any offence either in Malawi or in his home country - Tanzania. Had it not been for the intervention of the court he would have been transferred ${ }^{61}$ Courts could also be petitioned should the prisoner be of the view that the

57 This has been the case, for example, in South Africa. See generally Jamil Ddamulira Muuzi, Towards the Establishment of a Prisoners Transfer Legal Regime in South Africa: Failed Attempts, Available Options and Critical Issues to Consider, African Journal of International and Comparative Law 20(2) (2012), pp. $281-300$.

58 Hansard of the House of Commons, text of 17 July 2007: Column 270W; Hansard of the House of Commons, text of 23 February 2009: Columns 354W - 355W.

59 See discussion below on people subject to transfer.

60 Section 6(2) of the Tanzania Transfer of Prisoners Act, No.10, 2004 provides that a prisoner who has been aggrieved by the Minister's decision to transfer him or her can appeal to the court.

61 See Banja v Republic (Misc Criminal Case No.136 of 2000)[2000]MWHC 31 (17 November 2000). The High Court held that the attempted transfer was illegal as the applicant was a suspect and not an offender and therefore the transfer of prisoners legislation was not applicable. 
decision by the relevant authorities to refuse to consent to his transfer to his country of nationality or citizenship is unreasonable. ${ }^{62}$ However, courts and offenders should be aware of the fact that legislation in African countries does not provide for an offender's right to be transferred and that jurisprudence emanating from the European Court of Human Rights, ${ }^{63}$ the United Kingdom, ${ }^{64}$ Canada $^{65}$ and the United States of America ${ }^{66}$ is to the effect that an offender does not have a right to be transferred. The third reason for expressly providing for the role of the judiciary in the transfer of offenders is to avoid a situation where some judicial officers could wrongly hold that because the prisoner transfer legislation does not expressly allow them to hear cases relating to the transfer, they lack jurisdiction to entertain any challenge to the transfer. An offender should have the right to appeal against such a decision otherwise this would put him outside the protection of the law. This is what happened in Swaziland. In $R v$ Machava and Others ${ }^{67}$ the accused, who were foreign nationals, were convicted of drug trafficking and sentenced to between 5 and 7 years' imprisonment. In her submission before the sentences were imposed,

62 In the USA and Canada there have been numerous decisions in which prisoners have challenged the decision not to be transferred as unreasonable. In Lebon v. Canada (Minister of Public Safety and Emergency Preparedness) 2012 CarswellNat 5014, 2012 FC 1500, 104 W.C.B. (2 d) 769 where the Minister refused to consent to the offender's transfer from the USA to Canada without providing any reasonable ground, the Federal Court of Appeals ordered the Minister to consent to the offender's transfer. The court made the following order (at para 27): 'In the better administration of justice, the Court seems fit to order the Minister to act in accordance with the directions of the Court within 45 days of the judgment. More particularly, the Minister shall be directed to accept the transfer request made by the applicant and confirm in writing to the applicant that all reasonable steps have been taken for his prompt transfer to a correctional facility in Canada.' In Iqbal Aujla v.U.S. Department of Justice, et al.2007 WL 1074469 (M.D.Pa.) 1 the court held that the Attorney General's decision to refuse to consent to the offender's transfer to his country of nationality has to be exercised reasonably as such decisions are subject to judicial review.

63 In Plepi v Albania and Greece (2010) 51 E.H.R.R. SE3 at p 53 the European Court of Human Rights held that the offender did not have a right to be transferred to serve his sentence in his country of nationality.

64 In McKinnon v Government of the United States of America and Another [2008] UKHL 59, para 36 the House of Lords held that 'the Convention [on the Transfer of Sentenced Persons] confers no rights on prisoners: a state is not obliged to comply with a repatriation request nor to provide reasons if it refuses to do so.'.

65 In Dudas v. Canada (Minister of Public Safety \& Emergency Preparedness) 2010 CarswellNat 3447, 2010 FC 942, 14 Admin. L.R. (5th) 123, 373 F.T.R. 253 (Eng.) para 30, the court held that 'transfers under the ITOA are a discretionary privilege for offenders incarcerated abroad. There is no right to a transfer under the ITOA at any time.'.

66 In David F. Bagguley v.George W. Bush, President of the United States 953 F.2d 660, 293 U.S.App.D.C. 264, 663, 267 in which the court held that 'Bagguley has not demonstrated violation of a treaty because he has not shown-indeed cannot show-that the Convention requires international transfer of a prisoner upon request.'.

$67 R v$ Machava and others [2010] SZHC 204 (Judgment of 29 January 2010). 
[21] Mrs. Dlamini, for the Crown, referred the Court to the provisions of The Transfer of Convicted Offenders Act, 2001 and urged the Court to recommend that the Minister for Justice should invoke it and request for the convicts in the instant case to be transferred to their respective administering countries or those with which they have close ties in the event a custodial sentence is imposed. I decline that invitation having particular regard to the provisions of section 3 (2) of the Act, which stipulates the persons at whose instance the transfer may be made. These include the Minister for Justice, the administering country or the convict himself. [22] It is clear that this Court is not one of the parties that has the right to initiate such a process and does not appear to have any role in the transfer of such a convict. If this country is of the view that these are proper cases in which to invoke the provisions of the Act, then the Directorate of Public Prosecutions may be the appropriate authority, in the circumstances, to advise and make appropriate recommendations to the Minister. The transfer, it would seem to me, regard being had to section 5 (1) (d), would only be consummated once the convicts themselves consent to be so transferred. It would therefore be wise to confer with them in any event before any decision even to approach the Minister is taken by the Crown in this matter. ${ }^{68}$

The court held that in terms of the Act it 'does not appear to have any role in the transfer' of an offender from Swaziland to another country. The Act does not expressly state the role of the court in the transfer of an offender. It is argued that the fact that the Act is silent on the role of the court in the transfer of offenders does not mean that the court does not have any role to play in the transfer process. Section 5(1)(d) of the Swazi Transfer of Convicted Offenders Act ${ }^{69}$ provides that the transfer of the offender can only take place with his or her consent. Such consent has to be given voluntarily and in writing. ${ }^{70}$ It is submitted that if an attempt is made to transfer an offender without his or her consent, there is nothing in the Act that bars the offender from petitioning the court to prevent his or her transfer. The offender could petition the High Court to have his transfer halted on the basis that it would be contrary to the Act. ${ }^{71}$ Another way in which the court could intervene is if the offender argues that his transfer would violate any of his rights in the Constitution and he petitions the High Court to stop such transfer. ${ }^{72}$ Therefore, although the Act does not specifically envisage the role of a court in the transfer process, there are situations where a court will have to intervene. However, to avoid a situation where offenders are left to the mercy of courts exercising their inherent

$68 R v$ Machava and others [2010] SZHC 204 (Judgment of 29 January 2010) paras 21 and 22.

69 Act 10 of 2001.

70 Section 5(2).

71 Article 151(1)(a) of the Constitution provides that the High Court has unlimited original jurisdiction in civil and criminal matters.

72 Article 151(2)(a) of the Constitution provides that the High Court has jurisdiction 'to enforce the fundamental human rights and freedoms guaranteed' by the Constitution. 
jurisdiction, it is preferable that the law expressly empowers courts to have a role in the transfer of offenders.

\section{Consent of the offender before the transfer}

The consent of both the sentencing state and the enforcement state is generally necessary before an offender can be transferred. ${ }^{73}$ This is so because one state is being asked to enforce a sentence that was imposed on an individual who did not break its laws and who was not convicted by its courts. This consent is needed because in international law states are equal sovereigns a principle that is also emphasised in Article 4 of the Convention against Corruption.

One of the challenges likely to be confronted in the transfer of offenders between different countries is that of the consent of the offender before the transfer. This is because the issue of the offender's consent has been dealt with differently by different African countries. National legislation in Mauritius, ${ }^{74}$ Namibia, ${ }^{75}$ Uganda $^{76}$ Swaziland, $^{77}$ Ghana,${ }^{78}$ and Tanzania ${ }^{79}$ requires that a prisoner can only be transferred when he has expressly consented to the transfer or has applied to be transferred. The Nigerian prisoner transfer law was amended in 2011 to exclude a prisoner's consent as one of the requirements for the transfer. ${ }^{80}$ The Zambian Transfer of Convicted Persons Act is different from the other pieces of legislation on the transfer of offenders in Africa in the sense that it provides that the application for the transfer of a convicted person to serve his sentence in Zambia or in a foreign country could be made by (i) the convicted person (in the case of Zambian nationals), (ii) the Attorney-General in the case of a Zambian national, and an appropriate authority in the case of a foreign national, (iii) a relative, or (iv) any other interested person or body. ${ }^{81}$ If a Ugandan national, for example, is convicted of corruption in Nigeria, his transfer might be a challenge for both countries. This

73 There is an exception under the European system. With the exception of a few instances, European countries are now under an obligation to enforce sentences imposed on their nationals by courts of other countries. See Council Framework Decision 2008/909/JHA of 27 November 2008 on the application of the principle of mutual recognition to judgements in criminal matters imposing custodial sentences or measures involving deprivation of liberty for the purpose of their enforcement in the European Union.

74 Sections 3A and 4 of the Transfer of Prisoners Act, Act No. 10 of 2001.

75 Sections 4(1)(d) and 8 of the Transfer of Convicted Offenders Act, Act No. 9 of 2005.

76 Sections 6(d) and 9 of the Transfer of Convicted Offenders Act, 2012.

77 Section 5.

78 Section 4(g) of the Transfer of Convicted Persons Act, Act No. 743of 2007.

79 Section 5 of the Transfer of Prisoners Act, Act No.10 of 2004.

80 Section 8 of the Transfer of Convicted Offenders (Enactment and Enforcement) Act, Chapter T16, 1988 required the offender's consent before the transfer. But in 2011 the Transfer of Convicted Offenders (Enactment and Enforcement)(Amendment) Act, 2011, which deletes section 8 of the main Act, was passed. The effect is that offender's consent is no longer a requirement for the transfer.

81 Sections 4 and 11(8) of the Transfer of Convicted Persons Act, Act No. 26 of 1998. 
is because in terms of Nigerian law such an offender could be transferred to Uganda without his consent but in terms of Ugandan law such an offender can only be transferred with his consent. The challenge is how would Nigeria deal with such an offender if it is convinced that he has to be transferred to Uganda? Nigeria would have one of the following options: to imprison the offender in such conditions that he would be indirectly forced to apply for or consent to his transfer to Uganda; ${ }^{82}$ or to detain the offender until he completes his sentence and thereafter deport him- hence failing to invoke Article 45 of the Convention against Corruption.

The question that has to be answered is whether the consent of the offender should be required before his transfer. This is not an easy question to answer. Some countries have realised that in many cases offenders decline to give consent for the transfer, and have decided to amend their legislation to exclude the offender's consent as a prerequisite for the transfer. This has been the case in the United Kingdom ${ }^{83}$ and Nigeria. The UK government put it very clearly in its explanatory memorandum on the transfer of offenders treaty with Uganda:

Most existing prisoner transfer agreements to which the United Kingdom is a party require the consent of both States involved, as well as that of the prisoner concerned. It is increasingly the case that many foreign national prisoners have no links with the country in which they are detained and will be removed at the end of their sentence by the authorities. As a consequence international prisoner transfer agreements are moving away from the idea that prisoners should have to consent to transfer and therefore have the power to exercise an effective veto over the transfer. ${ }^{84}$

The European Union has also taken measures to ensure that the offender's consent is not invoked to make it impossible for the transfer to take place. The first step was the amendment to the Convention on the Transfer of Sentenced Persons by enacting the Additional Protocol thereto and the enactment of Framework Decision 2008/909/JHA. ${ }^{85}$ The challenge is that if the offender is transferred without his consent, it becomes difficult to determine whether such transfer is indeed in his best interest. One of the rationales behind prisoner transfers is that

82 In The Queen on the Application of: Steven Willcox v Secretary of State for Justice [2009] EWHC 1483 (Admin) the offender, who had been transferred from Thailand, unsuccessfully argued that the horrible prison conditions in that country forced him to consent to the transfer and that as a consequence his consent to the transfer was not voluntary. In United States of America v. Robert Donahue 1994 WL 904692 (S.D.Fla.) 4 and Michael W. Tramel, James Caudill v. United States Parole Commission, 100 F.3 d 129, 10 Fla. L. Weekly Fed. C 556, 131 the courts agreed that the offenders had been imprisoned in appalling prison conditions in the Bahamas.

83 The Repatriation of Prisoners Act 1984 was amended by the Police and Justice Act 2006 to remove the requirement of the offender's consent to the transfer in all cases.

84 Explanatory Memorandum on an Agreement between the United Kingdom and Uganda on the Transfer of Sentenced Persons Para 7. See also the Explanatory Memorandum (Libya) para i, Explanatory Memorandum (Rwanda) para 7.

85 United Nations Office on Drugs and Crime, Handbook on the International Transfer of Sentenced Persons. New York 2012, p 20. 
they are made on humanitarian grounds and aimed at ensuring that the transferred offender would be rehabilitated. ${ }^{86}$ However, transfers without consent could defeat this objective. They could end up being disguised deportations ${ }^{87}$ That is why the role of the court is critical in ensuring that the transfer does not put the offender in the hands of a state that would violate his rights. This now brings me to the issue of human rights in the context of prisoner transfer.

\section{Human rights}

Legislation in African countries on prisoner transfer in Africa does not stipulate that one of the requirements for the transfer is that a prisoner's rights will be protected by the receiving state. In other words, for a transfer to take place, the receiving state does not have to assure the sending state that the prisoner's rights will not be violated after the transfer. However, African countries have national, international and regional obligations to protect the rights of prisoners, irrespective of whether they have been transferred from other countries or sentenced by their national courts. At the national level, prison legislation in countries, such as, Uganda, ${ }^{88}$ Malawi, ${ }^{89}$ Namibia, ${ }^{90}$ Ghana, ${ }^{91}$ and South Africa, ${ }^{92}$ provides for the rights of prisoners. At the regional level, the African Commission on Human and Peoples' Rights has made it very clear that states parties to the African Charter on Human and Peoples' Rights have an obligation to

86 Council Framework Decision 2008/909/JHA, preamble, para 9. In Jerome J. Scalise, et al.,v. Richard Thornburgh, et al 891 F.2 d 640, 645 - 646 the United States Federal Court of Appeals held that it was 'not unmindful of the fact that a salutary purpose of the Convention [on the Transfer of Sentenced Persons] is to further the social rehabilitation of international prisoners by providing for their transfer to their home countries.' In Tangorra v. Canada (Minister of Public Safety \& Emergency Preparedness)2011 CarswellNat 5406, 2011 FC 1433, 213 A.C.W.S. (3 d) 99, 401 F.T.R. 246 (Eng.) para 13, the Canadian Federal Court held that the fact that offenders serve their sentences in their countries of origin 'aids their rehabilitation and reintegration into society, and advances the administration of justice.'.

87 It has been argued that there are several policy considerations that lead countries to entering into prisoner transfer agreements. 'The main problems facing a foreign prisoner are the cultural and language barrier, the lack of rehabilitation programs and refusal of conditional release programs (due to the perceived flight risk), and the general prejudice faced by the foreign prisoner, other prisoners, and prison staff. Prisoner transfer agreements were seen as a way to alleviate these additional burdens on the foreign prisoner. However, it would appear that these treaties are now also seen as a method by which the sentencing country can expel foreign prisoners and relieve itself of a considerable financial strain, which is a motive which runs contrary to the humanitarian goals of these treaties.' See M. Cherif Bassiouni, United States Policies and Practices on Execution of Foreign Sentences, in: M. Cherif Bassiouni (ed.) International Criminal Law: Multilateral and Bilateral Enforcement Mechanisms: Volume II, Leiden 2008, p. 588.

88 Section 57 of the Prisons Act, 2006.

89 Prisons Bill, 2003, sections 5, 6, 11, 13, 15, 21, and 42(4).

90 Prisons Act No.17 of 1998, sections 66 and 67.

91 Section 38 of the Prison Service Act, 1972.

92 Correctional Services Act, 111 of 1998, sections $7-18$. 
protect the rights of prisoners. ${ }^{93}$ It is against this backdrop that the African Commission has established the office of the Special Rapporteur on Prisons and Conditions of Detention in Africa with the mandate to work hand in hand with African countries and NGOs to improve prison conditions in Africa. ${ }^{94}$ The challenge is that poor prison conditions in many African countries could be a stumbling block to the transfer of convicted persons not only within Africa but also to Africa from other countries. At the international level, human rights bodies or mechanisms, such as, the Committee against Torture ${ }^{95}$ the Human Rights Committee ${ }^{96}$ the UN

93 See Jamil Ddamulira Mujuzi, The Role of Civil Society in Protecting and Promoting Prisoners Rights before the African Commission on Human and Peoples' Rights, International Journal of Civil Society Law V:III (2007), pp. 18 - 28.

94 For a detailed discussion of the role of the Special Rapporteur on Prisons and Conditions of Detention in Africa, see Frans Viljoen, The Special Rapporteur on Prisons and Conditions of Detention in Africa: Achievements and Possibilities, Human Rights Quarterly 27 (2005), pp. 125 - 171.

95 Concluding Observations of the Committee against Torture on Morocco's fourth periodic report, CAT/C/MAR/CO/4, 21 December 2011, para 19; Concluding Observations of the Committee against Torture on Djibouti's initial report, CAT/C/DJ/CO/1, 22 December 2011, para 12; Concluding Observations of the Committee against Torture on Zambia's second periodic report, $\mathrm{CAT} / \mathrm{C} / \mathrm{ZMB} / \mathrm{CO} /$ 2, 26 May 2008, para 15; Concluding Observations of the Committee against Torture on South Africa's initial report, CAT/C/ZAF/CO/1, 7 December 2006, para 22; Concluding Observations of the Committee against Torture on Chad's initial report, CAT/C/TCD/CO/1, 4 June 2009, para 25; Concluding Observations of the Committee against Torture on Madagascar's initial report, $\mathrm{CAT} / \mathrm{C} /$ MDG/CO/1, 21 December 2011, para 10; Concluding Observations of the Committee against Torture on Cameroon's fourth periodic report, $\mathrm{CAT} / \mathrm{C} / \mathrm{CMR} / \mathrm{CO} / 4,19$ May 2010, para 15; Concluding Observation of the Committee against Torture on Benin's second periodic report, $\mathrm{CAT} / \mathrm{C} / \mathrm{BEN} / \mathrm{CO} / 2$, 19 February 2008, para 17; Concluding Observations of the Committee against Torture on Kenya's initial report, CAT/C/KEN/CO/1, 19 January 2009, para 15; Concluding Observations of the Committee against Torture on Mauritius' third periodic report, CAT/C/MUS/CO/3, 15 June 2011, para 14; Concluding Observations of the Committee against Torture on Ethiopia's initial report, CAT/C/ ETH/CO/1, 20 January 2011, para 26.

96 Concluding observations of the Human Rights Committee on Togo's third periodic report, CCPR/ CO/76/TGO, 28 November 2002, para 15; Concluding observations of the Human Rights Committee on Benin's initial report, $\mathrm{CCPR} / \mathrm{CO} / 82 / \mathrm{BEN}, 1$ December 2004, para 17; Concluding observations of the Human Rights Committee on Zambia's third periodic report, CCPR/C/ZMB/CO/3, 9 August 2007, para 23; Concluding observations of the Human Rights Committee on Malawi (without a periodic report), CCPR/C/MWI/CO/76/1, 18 June 2012 para 13; Concluding observations of the Human Rights Committee on Cameroon's fourth periodic report, CCPR/C/CMR/CO/4, 4 August 2010, para 21; Concluding observations of the Human Rights Committee on Madagascar's third periodic report, CCPR/C/MDG/CO/3, 11 May 2007, para 22; Concluding observations of the Human Rights Committee on the Democratic Republic of Congo's third periodic report, $\mathrm{CCPR} / \mathrm{C} / \mathrm{COD} / \mathrm{CO} /$ 3, 26 April 2006, para 20; Concluding observations of the Human Rights Committee on Gabon's second periodic report, $\mathrm{CCPR} / \mathrm{CO} / 70 / \mathrm{GAB}, 10$ November 2000, para 14; Concluding observations of the Human Rights Committee on Cape Verde (without a periodic report), CCPR/C/CPV/CO/1, 23 April 2012, para 14; Concluding observations of the Human Rights Committee on Uganda's initial report, CCPR/CO/80/UGA, 4 May 2004, para 18; Concluding observations of the Human Rights Committee on Chad's initial report, CCPR/C/TCD/CO/1, 11 August 2009 para 23; Concluding observations of the Human Rights Committee on The Gambia (without a periodic report), CCPR/CO/ 75/GMB, 12 August 2004, para 12; Concluding observations of the Human Rights Committee on 
Human Rights Review Mechanism, ${ }^{97}$ the UN Special Rapporteur on Torture, ${ }^{98}$ the UN Special Rapporteur on Violence against Women, ${ }^{99}$ the Working Group on Arbitrary Detention, ${ }^{100}$ and the UN Subcommittee on Torture, ${ }^{101}$ have expressed concern over poor and in some cases appalling prison conditions in Africa, and have called upon African countries to improve them. Article 3 of the Convention against Torture provides that ' $[\mathrm{n}] \mathrm{o}$ State Party shall expel, return ("refouler") or extradite a person to another State where there are substantial grounds for believing that he would be in danger of being subjected to torture.' Courts in some African countries have barred the deportation or extradition of people to countries where there is a risk that they would be subjected to torture. ${ }^{102}$ It should be recalled that the Committee against Torture has stated:

Tanzania's fourth periodic report, CCPR/C/TZA/CO/4, 6 August 2009, para 19; Concluding observations of the Human Rights Committee on Rwanda's third periodic report, $\mathrm{CCPR} / \mathrm{C} / \mathrm{RWA} / \mathrm{CO} /$ 3, 7 May 2009, para 15.

97 Report of the Working Group on the Universal Periodic Review: Gabon, A/HRC/8/35, 28 May 2008, para 27; Report of the Working Group on the Universal Periodic Review: Botswana, A/HRC/ 10/69, 13 January 2009, paras 33, 58, 63, 67, 92 and (19); Report of the Working Group on the Universal Periodic Review: Benin, A/HRC/8/39, 28 May 2008, paras 13, 14, 23, 27, 42, 43 and 56(17); Report of the Working Group on the Universal Periodic Review: Cape Verde, A/HRC/ 10/81, 12 January 2009, 35, 39, 45 and 62(10); Report of the Working Group on the Universal Periodic Review: Zambia, A/HRC/8/43, 2 June 2008, paras 8, 15, and 31; Report of the Working Group on the Universal Periodic Review: Morocco, A/HRC/8/22, 28 May 2008, paras 47 and 75(7); Report of the Working Group on the Universal Periodic Review: Burkina Faso,A/HRC/10/80, 7 January 2009, para 39, 40,41, 82 and 98(10); Report of the Working Group on the Universal Periodic Review: Mali, A/HRC/8/50, 13 June 2008, paras 23, 27 and 56(19).

98 Report of the Special Rapporteur on Torture and other cruel, inhuman or degrading treatment or punishment, Manfred Nowak: Mission to Togo, A/HRC/7/3/Add.5, 6 January 2008, paras33 - 41; Report of the Special Rapporteur on Torture and other cruel, inhuman or degrading treatment or punishment, Manfred Nowak: Mission to Nigeria, A/HRC/7/3/Add.4, 22 November 2007, paras 50 - 55; Report of the Special Rapporteur on Torture and other cruel, inhuman or degrading treatment or punishment, Juan E. Méndez: Mission to Tunisia, A/HRC/19/61/Add.1, 2 February 2012, paras $41-53$.

99 Report of the Special Rapporteur on Violence against Women, its Causes and Consequences, Yakin Ertürk: Mission to the Democratic Republic of Congo, A/HRC/7/6/Add.4, 28 February 2008, para $80-85$.

100 Report of the Working Group on Arbitrary Detention: Mission to Equatorial Guinea, A/HRC/7/4/ Add.3, 18 February 2008, paras 87 - 96.

101 Report on the Visit of the Subcommittee on Prevention of Torture and Other Cruel, Inhuman or Degrading Treatment or Punishment to Benin, CAT/OP/BEN/1, 15 March 2011, paras 179-228.

102 See Arwah Abdi and Another v Minister of Home Affairs and Others [2011] ZASCA 2 (15 February 2011) in which the South African Supreme Court of Appeal held that it would be unconstitutional for the Department of Home Affairs to return or deport the applicants to Somalia where there was a risk that they could be subjected to torture; in Mann v Republic of Equatorial Guinea (Case No. CA 507/07) [2008] ZWHHC 2 (23 January 2008) at pg 6, the High Court of Zimbabwe held that although Zimbabwe was not a state party to the Convention against Torture, 'Zimbabwe has an obligation not to extradite any person to a country where there are substantial grounds for believing 
The obligation to prevent torture in article 2 is wide-ranging. The obligations to prevent torture and other cruel, inhuman or degrading treatment or punishment (hereinafter "ill-treatment") under article 16, paragraph 1, are indivisible, interdependent and interrelated. The obligation to prevent ill-treatment in practice overlaps with and is largely congruent with the obligation to prevent torture. Article 16, identifying the means of prevention of ill-treatment, emphasizes "in particular" the measures outlined in articles 10 to 13, but does not limit effective prevention to these articles, as the Committee has explained, for example, with respect to compensation in article 14. In practice, the definitional threshold between ill-treatment and torture is often not clear. Experience demonstrates that the conditions that give rise to ill-treatment frequently facilitate torture and therefore the measures required to prevent torture must be applied to prevent ill-treatment. Accordingly, the Committee has considered the prohibition of ill-treatment to be likewise non-derogable under the Convention and its prevention to be an effective and non-derogable measure. ${ }^{103}$

The Committee against Torture has called upon states parties to the Convention against Torture, including some African countries, not to transfer detainees to countries where they are at a risk of being subjected to torture. ${ }^{104}$ Although the Committee against Torture has referred to detainees, the same recommendation is applicable with respect to the transfer of convicted persons. This means that African countries have an obligation to ensure that offenders are not transferred to countries where there is a risk that they would be subjected to torture or other cruel, inhuman or degrading treatment or punishment through, for example, their imprisonment in appalling prison conditions. ${ }^{105}$ It should also be recalled that Article 10(3) of the International Covenant on Civil and Political Rights (ICCPR) provides that ' $[\mathrm{t}]$ he penitentiary system shall comprise treatment of prisoners the essential aim of which shall be their reformation and social rehabilitation.'

that the person so expelled, returned or extradited would be in danger of being subjected to torture...'?

103 Committee against Torture General Comment No. 2 (Implementation of article 2 by states parties), $\mathrm{CAT} / \mathrm{C} / \mathrm{GC} / 2$, 24 January 2008 para 3.

104 Concluding Observation of the Committee against Torture on Chad's initial report, CAT/C/TCD/ CO/1, 4 June 2009, para 23; Concluding Observation of the Committee against Torture on Denmark's fifth periodic report, CAT/C/DNK/CO/5, 16 July 2007, para 13; Concluding Observation of the Committee against Torture on Benin's second periodic report, CAT/C/BEN/CO/2, 19 February 2008, para 11(c); Concluding Observation of the Committee against Torture on Djibouti's initial report, $\mathrm{CAT} / \mathrm{C} / \mathrm{DJI} / \mathrm{CO} / 1,22$ December 2011, para 14(c).

105 In Joined Cases C 411/10 and C 493/10 (21 December 2011), the Court of Justice of the European Community held that "Article 4 of the Charter of Fundamental Rights of the European Union must be interpreted as meaning that the Member States, including the national courts, may not transfer an asylum seeker to the "Member State responsible" ... where they cannot be unaware that systemic deficiencies in...the reception conditions of asylum seekers in that Member State amount to substantial grounds for believing that the asylum seeker would face a real risk of being subjected to inhuman or degrading treatment within the meaning of that provision.'. 
In the light of the fact that the prison conditions in many African countries are poor, the question is asked whether the imprisonment of transferred offenders to such countries would not defeat the objective of Article 10(3) of the ICCPR. Poor prison conditions are not conducive to rehabilitation. The constitutions of many African countries prohibit cruel, inhuman or degrading treatment. ${ }^{106}$ Because of the poor prison conditions in some African countries, the UK government has reportedly offered to construct or renovate prisons in countries, such as, Uganda ${ }^{107}$ and Nigeria ${ }^{108}$ in conformity with internationally acceptable standards, before transferring offenders from the UK to serve their sentences in such prisons. It is argued that the transfer of an offender to a country where he would be imprisoned in conditions that fall below internationally acceptable standards would be a violation of that person's right to freedom from cruel, inhuman and degrading treatment or punishment. Such transfer should not be authorised by the sending state and should not be accepted by the receiving state. But the issue becomes quite complicated in cases where the prison conditions in the sentencing state are worse than those in the enforcement state although those of the latter could also be below internationally acceptable standards. Should the prisoner be transferred in such a case? It is argued that the prisoner should be transferred from worse prison conditions to bad prison conditions, but that, the administering state should make an effort to improve its prison conditions.

Another important issue in prisoner transfer arrangements is whether the offender's trial in the sentencing country was fair. The constitutions of all African countries provide for the

106 For example, Article 7(1) of the Constitution of Botswana provides that ' $\mathrm{n}] \mathrm{o}$ one shall be subjected to torture or to inhuman or degrading punishment or other treatment'; Article 8(1) of the Constitution of Lesotho provides that ' $[\mathrm{n}] \mathrm{o}$ one shall be subjected to torture or to inhuman or degrading punishment or other treatment'; Article 40(1) of the Constitution of Mozambique provides that '[a]ll citizens shall have the right to life and to physical and moral integrity, and they shall not be subjected to torture or to cruel or inhuman treatment'; Section 12(1)(d) and (e) of the Constitution of South Africa provide that ' $[\mathrm{e}] \mathrm{very}$ one has the right to freedom and security of the person, which includes the right - not to be tortured in any way; and not to be treated or punished in a cruel, inhuman or degrading way'; Article 13(6)(e) of the Constitution of Tanzania provides that 'no person shall be subjected to torture or inhuman or degrading punishment or treatment'; Article 15 of the Constitution of Zambia provides that '[n]o person shall be subjected to torture, or to inhuman or degrading punishment or other like treatment'; Article 16 of the Constitution of Seychelles provides that '[e]very person has a right to be treated with dignity worthy of a human being and not to be subjected to torture, cruel, inhuman or degrading treatment or punishment'; and Article 18(2) of the Constitution of Swaziland provides that '[a] person shall not be subjected to torture or to inhuman or degrading treatment or punishment.'.

107 Raymond Baguma, UK Funds Luzira prison rehabilitation, 4 September 2009, The New Vision, at http://www.newvision.co.ug/D/8/13/693494 (last accessed on 23 November 2013).

108 See James Slack, Britain "to Build $£ 1 \mathrm{~m}$ Jail in Nigeria" for 400 prisoners serving sentences here, 9 July 2009, Mail on Line at http://www.dailymail.co.uk/news/article-1198401/Britain-build-3mjail-Nigeria-400-prisoners-serving-sentences-here.html (last accessed on 23 November 2013); see also Uk to Build Prisons in Nigeria,Plans to send Home 594 Prisoners, http://www.naijahottestgis t.com/2013/04/27/uk-to-build-prisons-in-nigeriaplans-to-send-home-594-prisoners/ (last accessed on 23 November 2013). 
right to a fair trial. ${ }^{109}$ This right is also protected under Article 7 of the African Charter on Human and Peoples' Rights, and the African Commission on Human and Peoples' Rights has developed a rich jurisprudence on this right. ${ }^{110}$ International human rights instruments, such as, the ICCPR, also protect the right to a fair trial. ${ }^{111}$ One concern that would have to be dealt with is whether an administering country would be obliged to continue with the enforcement of a sentence where there is evidence that the prisoner's conviction in the sentencing state was as a result of a trial that was not fair. Recently the African Commission on Human and Peoples' Rights found in Egyptian Initiative for Personal Rights and Interights $v$ Arab Republic of Egypt ${ }^{112}$ that the victims' convictions had been as a result of an unfair trial - inter alia, they had been tortured to make confessions that were relied on by the court to convict them, and the court was not independent - and recommended that they should be released from custody. This means that the African Commission considers the continued imprisonment of a prisoner whose conviction was as a result of an unfair trial to be a violation of the African Charter on Human and Peoples' Rights. On the other hand, the European Court of Human Rights in Drozd and Janousek $v$ France and Spain,${ }^{113}$ held that ' $[\mathrm{t}]$ he Contracting States are... obliged to refuse their co-operation [in enforcing a sentence] if it emerges that the conviction is the result of a flagrant denial of justice.' ${ }^{114}$ In his concurring opinion Judge Matscher held that 'a contracting State may incur responsibility by reason of assisting in the enforcement of a foreign judgment, originating from a contracting or a non-contracting State, which has been obtained in conditions which constitute a breach of Article 6...'115 The Court emphasised though, that

...the Convention does not require the Contracting Parties to impose its standards on third States or territories,... [and a contracting party is] not obliged to verify whether the proceedings which resulted in the conviction were compatible with all the requirements of Article 6 ... of the Convention. To require such a review of the manner in which a court not bound by the Convention had applied the principles enshrined in Article 6 ...would also thwart the current trend towards strengthening international coopera-

109 For the relevant provisions of the constitutions, see Christof Heyns (Ed),Human Rights Law in Africa Volume 1, Leiden/Boston 2004,. See also Article 50 of the Constitution of Kenya (2010); Article 44 of the Constitution of Egypt (2012); Article 23 of the Interim Constitution of South Sudan (2005); and sections 69 and 70 of the Constitution of Zimbabwe (2013).

110 See for example, Nsongurua J. Udombana, The African Commission on Human and Peoples' Rights and the Development of Fair Trial Norms in Africa, African Human Rights Law Journal 6 (2006), pp. $299-332$.

111 Article 14.

112 Egyptian Initiative for Personal Rights and Interights v Arab Republic of Egypt, Communication 334/06 (decided at the $9^{\text {th }}$ extra-ordinary session held from 23 February to 3 March 2011).

113 Drozd and Janousek v France and Spain, Application No. 12747/87, 26 June 1992.

114 Drozd and Janousek v France and Spain, para 110.

115 Drozd and Janousek v France and Spain, page 32. 
tion in the administration of justice, a trend which is in principle in the interests of the persons concerned. ${ }^{116}$

The United Kingdom High Court in Samantha Orobator v Governor of HMP Holloway and Secretary of State for Justice, ${ }^{117}$ held that the UK could not continue to enforce the sentence of an offender who had been transferred from another country to serve his sentence in the UK if the conviction had been the result of a flagrant denial of justice. The question that African countries would have to grapple with is whether a person who has been convicted of an offence under the Convention against Corruption after a trial which, if had been conducted in the administering state would have been found to be unfair, would continue to serve his sentence in the administering state. Jurisprudence from the European Court of Human Rights and the UK shows that the mere fact that the trial had been unfair by the standards of the administering state does not mean that the continued enforcement of the sentence would be unlawful. The threshold, which is a high one indeed, is whether there was a flagrant denial of justice. As the UK High Court explained:

...[H]er claim that she has been detained in the UK unlawfully cannot succeed unless it is shown that she suffered a flagrant denial of justice in Laos. For the reasons that we have given, she has not been able to satisfy this high test. The test is rightly set very high. That is because it is important not to jeopardise or undermine the treaties for the repatriation of prisoners which the UK now has with many countries, so that those who are convicted abroad can serve their sentences here. If persons who have been convicted and sentenced abroad and have procured their transfer to the UK were easily able to obtain their liberty by challenging the fairness of their convictions, there would be a grave danger that these important treaties would be set at nought. That would be highly regrettable. ${ }^{118}$

It is argued, that because African countries have different judicial systems and rules of evidence and procedure, some transferred offenders could challenge their continued imprisonment in the enforcement state on the ground that their conviction in the sentencing state was as a result of an unfair trial. In dealing with such challenges, courts are encouraged to refer to the jurisprudence from the UK and the European Court of Human Rights. They should bear in mind, as the UK High Court cautioned, that if transferred offenders are easily released this could defeat the objective of the transfer arrangements. Some countries refuse to consent to the offender's transfer if his sentence would be drastically reduced in the administering coun-

116 Drozd and Janousek $v$ France and Spain, para 110.

117 Samantha Orobator v Governor of HMP Holloway and Secretary of State for Justice [2010] EWHC 58 (Admin).

118 Samantha Orobator v Governor of HMP Holloway and Secretary of State for Justice [2010] EWHC 58 (Admin) para 140. 
try. ${ }^{119}$ One has to recall that the offences under the Convention against Corruption are serious ones and that those who have been convicted of them should not be allowed to easily escape punishment by challenging the circumstances in which they were convicted. Apart from the rights to freedom from torture and cruel, inhuman or degrading treatment or punishment as well as the right to a fair trial, some African countries are known to be violating many other rights, such as, the right to freedom of religion, the right to freedom from discrimination, the right to human dignity, and the right to vote.The sentencing country should assess whether the transfer of an offender would not violate its national and international human rights obligations. The administering country should also ensure that it does not enforce a sentence in a manner that violates the rights of the offender. The fact that an offender has consented to his or her transfer does not mean that he/she waives their rights.

\section{Sentences}

Another critical issue in the prisoner transfer arrangement and in particular under Article 45 of the Convention against Corruption relates to the sentence that will be imposed on the offender and the manner in which it will be enforced. This issue is related to but separate from that relating to conditions of detention discussed above. Article 30(1) of the Convention against Corruption requires states parties to 'make the commission of an offence established in accordance with this Convention liable to sanctions that take into account the gravity of that offence.' During the drafting of the Convention, some delegations submitted that states parties should prescribe minimum sentences, for example, four years' imprisonment, for those convicted of some of the offences under the Convention. ${ }^{120}$ Article 30(4) obliges states parties to 'take into account the gravity of the offences concerned when considering the eventuality of early release or parole of persons convicted of such offences.' My interpretation of Article 30 , as shown below, is that it allows both custodial and non-custodial sentences. The drafting history of Article 30 shows that some of the factors that were proposed to be considered in the release of offenders include 'the negative results caused by corruption', 121 'the grave nature of the offences' ${ }^{122}$, and 'the grave [and special] nature of the offences'. ${ }^{123}$ The drafting history of Article 30 also shows that states parties did not even consider the possibility of non-cus-

119 For example, in Paul Denham v. Correctional Officer Aranda, et al 2012 WL 3561988 (S.D.Cal.) 1 , the Governor of California refused to consent to the prisoner's transfer to the UK 'because "the United Kingdom would not administer [his] sentence in a manner consistent with California law".' In The Queen on the Application of: Steven Willcox $v$ Secretary of State for Justice [2009] EWHC 1483 (Admin) para 87 the court states that Thailand refused to sign a prisoner transfer agreement with The Netherlands because the latter had insisted on the possibility of being able to convert the sentences of its nationals transferred from Thailand.

120 Note 28, p. 220.

121 Note 28, p. 251.

122 Note 28, p. 253.

123 Note 28, p. 255. 
todial sentences. All the drafts that were debated indicate that the delegates exclusively referred to custodial sentences. ${ }^{124}$ However, because of the fact that Article 30 does not oblige states parties to impose only custodial sentences, pieces of legislation on corruption in some African countries indicate that offences under the Convention against corruption attract both custodial and non-custodial sentences as a person convicted of corruption is 'liable' to be sentenced to imprisonment or to a fine or both ${ }^{125}$ and in Rwanda a person convicted of corruption 'shall' be sentenced to imprisonment ranging between two and ten years and (not or) to a fine. ${ }^{126}$ The Convention does not expressly say that the offender's prospect of rehabili-

124 Note 28, p. $249-262$.

125 For example, section 26(1) of the Ugandan Anti-Corruption Act No. 6 of 2009 provides that "[a] person convicted of [corruption] is liable on conviction to a term of imprisonment not exceeding ten years or a fine not exceeding two hundred and forty currency points or both'; section 26 of the South African Prevention and Combating of Corrupt Activities Act No. 12 of 2004 provides that a person convicted of corruption is liable to imprisonment from three years to life imprisonment or to a fine or both; section 36 of the Botswana Corruption and Economic Crime Act No. 13 of 1994 (liable 10 years' imprisonment or a fine or both); section 49 of the Namibian Anti-Corruption Act No. 8 of 2003 (liable to a fine or imprisonment not exceeding 25 years or both); see also sections $15-36$ of the Tanzanian Prevention and Combating of Corruption Act, Cap 329 which emphasise imprisonment and fines; section 48 of the Kenyan Anti-Corruption and Economic Crimes Act, 2003; section 34 of the Malawian Corrupt Practices Act Chapter 7:04 provides that '[a]ny person who is guilty of an offence under this Part shall be liable to imprisonment for twelve years'; section 68 of the Nigerian Corrupt Practices and other Related Offences Act No. 5 of 2000 (liable to a fine or to imprisonment not exceeding two years or both); sections 4-17 of the Mauritian Prevention of Corruption Act No. 5 of 2002; sections 35 of the Swaziland Prevention of Corruption Act, No. 3 of 2006 (liable to imprisonment for between 10 and 20 years or a fine or both); section 34 of the Lesotho Prevention of Corruption and Economic Offences Act No. 5 of 1999 (liable to imprisonment for between five and 10 years or fine or both) and sections 26-52 of the Sierra Leonean Anti-Corruption Act, 2008. The fact that the offender is 'liable' to be sentenced to imprisonment or to pay a fine has been relied on by courts in Uganda to impose custodial sentences to some people who have been convicted of corruption. In Uganda v Keba Isaac [2013] UGHC 86 (25 April 2013) the Ugandan High Court convicted the accused of embezzlement contrary to the Anti-Corruption Act and sentenced him to five years' imprisonment. The court held that although the accused was a first offender, the "custodial sentence [was] suitable to remind the convict and persons of similar attitude that crime does not pay.' In Uganda v. Kilama Denis and 10 Other [2011] UGHC 21, the first accused was sentenced to six years' imprisonment for corruption; in Uganda v Namuyimba \& Another [2012] UGHC 48 the accused were sentenced to four years and 18 months' imprisonment respectively for corruption; in Uganda v Chemisto Alfred Mashandich and Others [2010] UGHC 50 the offenders were sentenced to between four and five years' imprisonment and ordered to compensate their former employer, the local government, for the loss incurred because of their corrupt activities; in Uganda v Imere Deo [2011] UGHC 82, the offender was sentenced to three years' imprisonment for corruption although the court observed that he was a first offender, a young man and had a family to take care of; in Uganda v Kaluuma Abdul Khariim [2012] UGHC 9 the offender was sentenced to seven years' imprisonment for corruption although the court noted that he was a young man, first offender and had a family to support; and in Uganda $v$ Ndifuna Moses [2009] UGHC 83 the accused was sentenced to two years' imprisonment for corruption.

126 Articles 10 - 26, Law No 23/2003 Related to the Punishment of Corruption and Related Offences, $07 / 08 / 2003$. 
tation should also be considered in his early release or parole. It is reported that during the drafting of Article 30(4) 'one delegation proposed the deletion of this paragraph, while some delegations expressed concern about its mandatory nature.' ${ }^{127}$ Despite those concerns, the provision was passed. The gravity of the offence is one of the factors that the relevant authorities are required to consider in deciding whether the offender should be placed on parole or released early and nothing bars them from considering reintegration as provided for under Article 30(10). The challenge presented by Article 30(4) is that the offender is likely to be prejudiced in that the gravity of the offence would be relevant at two critical stages relating to the deprivation of his liberty. At sentencing stage, one of the factors that courts normally consider in imposing sentence is the gravity of the offence; the more serious the offence the heavier the penalty. At the release stage, it is more likely that the parole board, where such a board exists, would be reluctant to recommend the early release of a person who was convicted of a serious offence. It is argued that this would be unfair and that at the time of determining whether or not the offender should be released early, the gravity of the offence should not be a factor. The guiding factor should be whether the offender in question would easily be reintegrated, as provided for under Article 30(10).

Article 30(10) provides that 'States Parties shall endeavour to promote the reintegration into society of persons convicted of offences established in accordance with this Convention.' It should be mentioned that the provision refers to 'reintegration' as opposed to rehabilitation. It has been mentioned earlier that Article 10(3) of the ICCPR provides that ' $[t]$ he penitentiary system shall comprise treatment of prisoners the essential aim of which shall be their reformation and social rehabilitation.' It could be argued there is a tension between Article 30(1) and (4) of the Convention against Corruption and Article 10(3) of the ICCPR in the sense that the Articles 30(1) and (4) emphasise the retribution and deterrence objectives of punishment whereas Article 10(3) emphasise rehabilitation. ${ }^{128}$ The question that arises is how to resolve this tension in the light of the fact the Convention against Corruption does not provide that the obligations incurred under Article 30 shall not 'affect the obligations under any other treaty, bilateral or multilateral, that governs or will govern, in whole or in part' the issue of punishment or sentencing. ${ }^{129}$ Could Article 30 of the Vienna Convention on the Law of Treaties (VCLT) be of help in this regard? Article 30 of the VCLT provides:

1. Subject to Article 103 of the Charter of the United Nations, the rights and obligations of States Parties to successive treaties relating to the same subject matter shall be determined in accordance with the following paragraph

2. When a treaty specifies that it is subject to, or that it is not to be considered as incompatible with, an earlier or later treaty, the provisions of that other treaty prevail.

127 Note 28, p. 255, note 25 .

128 The drafting history of Article 30 shows that one of the submissions made was that states parties should ensure that the prosecution of crimes under the Convention is done "with due regard to the need to deter the commission of such offences.' See note 28, p. 250.

129 However, see Article 46(6) of the Convention against Corruption on the issue of mutual legal assistance. 
3. When all the parties to the earlier treaty are parties also to the later treaty but the earlier treaty is not terminated or suspended in operation under article 59, the earlier treaty applies only to the extent that its provisions are compatible with those of the later treaty.

4. When the parties to the later treaty do not include all the parties to the earlier one: $(a)$ as between States Parties to both treaties the same rule applies as in paragraph 3; (b) as between a State party to both treaties and a State party to only one of the treaties, the treaty to which both States are parties governs their mutual rights and obligations.

5. Paragraph 4 is without prejudice to article 41 , or to any question of the termination or suspension of the operation of a treaty under article 60 or to any question of responsibility which may arise for a State from the conclusion or application of a treaty the provisions of which are incompatible with its obligations towards another State under another treaty. The first issue is whether Article 30 of the VCLT is applicable, because Article 2(1)(a) of the VCLT defines a treaty as 'an international agreement concluded between States in written form and governed by international law, whether embodied in a single instrument or in two or more related instruments and whatever its particular designation.' It is beyond dispute that both the ICCPR and the Convention against Corruption are treaties within the meaning of Article 30 of the VCLT. The problem is that the Convention against Corruption does not replace or purport to replace the ICCPR. This is understandable because each of the treaties deals with different subject matters - the ICCPR with human rights, and the Convention on Corruption with corruption although it also contains provisions on human rights. ${ }^{130}$ What we are confronted with is a situation where provisions in a subsequent treaty, Article 30(1), (4) and (10) of the Convention against Corruption, are potentially in conflict with a provision in an earlier treaty, Article 10(3) of the ICCPR. This is so because the Convention against Corruption emphasises retribution and deterrence as the objectives of punishment whereas the ICCPR emphasises rehabilitation irrespective of the offence for which the offender has been sentenced to imprisonment. Let us assume that the VCLT is applicable in the sense that we take 'the treaty' to include 'part thereof' - and in this case these specific Articles.

Article 30(2) of the VCLT is not applicable because the Convention against Corruption (Article 30) does not say that it is subject to the ICCPR (Article 10(3)) or that it is not to be considered as incompatible with Article 10 of the ICCPR. The applicable provision could be Article 30(3) or Article 30(4) of the VCLT. This is in respect of states parties to both treaties. The ICCPR is neither terminated nor suspended. Article 10(3) of the ICCPR applies only to the extent that it is compatible with Article 30 of the Convention against Corruption. In other words, Article 30(4) of the Convention against Corruption takes precedence over Article 10(3) of the ICCPR. This means that with respect to offences under the Convention against Corruption, the objectives of punishment should be retribution and deterrence. Article 30(4) of the VCLT is also applicable, with the necessary modifications.

The drafting history of Article 30 of the Convention against Corruption could be invoked to argue that this Article does not give states an opportunity to impose non-custodial sentences. 
This would be problematic especially in the light of the fact that the same Convention emphasises the independence of the judiciary ${ }^{131}$ and the issue of sovereignty. It should be left to the discretion of the judicial officer, as is the case with legislation on corruption in many African countries, to determine whether, depending on the circumstances of the accused, the manner in which the offence was committed, and the purpose of the punishment that is to be imposed, an offender should be sentenced to a custodial or to a non-custodial sentence. The question that would have to be answered before the transfer on an offender is whether his transfer would promote his re-integration, because his early release or parole would take place in the enforcement country. The question is whether, if it is established that his re-integration would take place better in the sentencing country, he would be allowed by the sentencing country, of which he is not a national, to return and live there. This is especially the position of people like permanent residents, who are domiciled in countries of which they are not nationals but with which they have close ties, especially close family ties. It is argued that in the light of the fact that Article 30(1) provides that state parties have an obligation to 'make the commission of an offence established in accordance with this Convention liable to sanctions that take into account the gravity of that offence', nothing bars a state party from empowering its judicial officers to impose non-custodial sentences in cases where a custodial sentence is not called for. Had the drafters of the Convention against Corruption wanted to exclude the possibility of the imposition of non-custodial sentences, they would have expressly stated so.

Another important issue that relates to sentence is whether the sentence imposed on the transferred offender will have to be converted in the administering state, or whether the administering state would have to continue with the enforcement of the sentence which was imposed in the sentencing state. The answer to that question could determine whether the offender, if his consent is a requirement for his transfer, would agree to the transfer or not. Legislation in all African countries provides for one option: the continued enforcement of the sentence imposed by the sentencing state. For example, section 12 of the Nigerian Transfer of Convicted Offenders (Enactment and Enforcement) Act provides that:

(1) The administering country shall be bound by the legal nature and duration of the sentence as imposed by the sentenc[ing country]

(2) The administering country may, if its law requires, by court or administrative order adopt the sanction to a punishment or measure prescribed by its own laws however that in so doing, the administering country shall ensure that - (a) the nature, punishment or measure so adopted shall, as far as possible, correspond with that imposed by the judgement of the sentencing country; and (b) the nature or duration of punishment so adopted does not aggravate the nature or duration of the sanctions by the sentencing country.

The transfer of offenders legislation in Swaziland, ${ }^{132}$ Mauritius (it is the offender who makes application to a judge of the High Court for the nature or duration of the sentence to be

131 Article 11.

132 Sections 8(4) and (5). 
adapted), ${ }^{133}$ Namibia, ${ }^{134}$ Tanzania, ${ }^{135}$ Uganda, ${ }^{136}$ and Ghana ${ }^{137}$ are also more or less drafted in the same manner as section 12 of the Nigerian Transfer of Convicted Offenders (Enactment and Enforcement) Act. The agreements/treaties on the transfer of offenders between the UK and Uganda, ${ }^{138}$ Libya, ${ }^{139}$ Rwanda, ${ }^{140}$ Ghana, ${ }^{141}$ Egypt, ${ }^{142}$ and Morocco ${ }^{143}$ also provide for continued enforcement, and where this is incompatible with the laws of the administering country, such country can adapt the sentence to be in accordance with its laws. The Zambian Transfer of Convicted Persons Act provides for the continued enforcement of the transferred offender's sentence and does not allow Zambia to adapt the sentence in question. Section 4(6) provides that ' $[\mathrm{t}]$ he conviction or sentence of a convicted person transferred to Zambia under this Act shall not be subject to any appeal or review in Zambia.' Section 7 provides that '[a] transferred person shall be imprisoned in Zambia for the unexpired term of the convicted person's imprisonment' although that person could be released on parole in terms of the Prisons Act. Like the Zambian legislation, the Zimbabwean Transfer of Offenders Act provides that " $[t]$ he conviction or sentence of an offender transferred to Zimbabwe in terms of this Act shall not be subject to any appeal or review in Zimbabwe.' ${ }^{144}$ The following should be noted about the above pieces of legislation: as mentioned earlier, in the case of Mauritius, the prisoner has a duty to apply to a judge of the High Court for his sentence to be adapted to one that is in accordance with Mauritian law. The offender is therefore expected to know the law and the procedure that has to be followed to have his sentence adapted. It is recommended that legal assistance or advice should be given to the offender to be able to make that application. In the case of Tanzania, the law stipulates that it is for the president of the country to exercise his prerogative of mercy under the Constitution to adapt the sentence in question. Section 16 of the Act provides:

Notwithstanding the provisions of this Act, where the sentence imposed by the foreign country upon a sentenced prisoner who is transferred to Tanzania by its nature or duration incompatible with any law of the United Republic of Tanzania, the President shall invoke the provisions of Article 45 of the Constitution...provided that, the legal

133 Section 6.

134 Section 13.

135 Section 16.

136 Section 15.

137 Section 9.

138 Article 7.

139 Article 7.

140 Article 7.

141 Article 7.

142 Article 11.

143 Article 13.

144 Section 6(2). See also section 7. 
nature of the sentence imposed shall so far as possible, correspond with that of the sentence imposed by a foreign country.

Article 45(1) of the Constitution provides:

Subject to the other provisions contained in this Article, the President may do any of the following: (a) grant a pardon to any person convicted by a court of law of any offence, and he may subject to law grant such pardon unconditionally or on conditions; (b) grant any person a respite, either indefinitely or for a specified period, of the execution of any punishment imposed on that person for any offence; (c) substitute a less severe form of punishment for any punishment imposed on any person for any offence; and (d) remit the whole or part of any punishment imposed on any person for any offence, or remit the whole or part of any penalty of fine or forfeiture of property belonging to a convicted person which would otherwise be due to the Government of the United Republic on account of any offence.

The applicable provision in the case of transfer is Article 45(1)(c). It is important to note the relationship between section 16 and Article 45 . Section 16 provides that in the case of a transfer where the sentence is incompatible with the laws of Tanzania the president 'shall' invoke his power under Article 45 and adapt the sentence accordingly. However, Article 45 provides that the president 'may' do any of the mentioned acts. This means that in the case of an offender who has been transferred to serve his sentence in Tanzania and the sentence is incompatible with the laws of Tanzania, the president has a constitutional obligation to invoke Article 45. He does not have a discretion whether or not to invoke it. He only has a discretion in respect of offenders who have been sentenced by Tanzanian courts.

The Council of Europe's Convention on the Transfer of Sentenced Persons gives states parties the option of continued enforcement (Article 10) or conversion (Article 11). The danger with continued enforcement is that it could discourage transfers as some countries may not be able to enforce the sentence that was imposed on the offender without being unfair to the prisoner. For example, the sentence for corruption involving one million dollars in country A could be 25 years' imprisonment and in country B a person convicted of the same offence could be liable to a sentence of not more than 15 years' imprisonment. If an offender is sentenced to 20 years' imprisonment in country A and transferred to country B, the latter should have the discretion to convert the sentence. This is what happened in Samantha Orobator $v$ Governor of HMP Holloway and Secretary of State for Justice.. ${ }^{145} \mathrm{Ms}$ Orabator was sentenced to life imprisonment for drug trafficking in Laos but her sentence was reduced to three years' imprisonment by the UK High Court because, in the court's opinion, if she had been convicted

145 Samantha Orobator v Governor of HMP Holloway and Secretary of State for Justice [2010] EWHC 58 (Admin). 
in the UK she could have been sentenced to not more than 3 years' imprisonment. ${ }^{146}$ It has also been an issue in the United States of America. ${ }^{147}$ Jurisprudence emanating from the European Court of Human Rights shows that there have been cases where an offender has pleaded guilty to the commission of an offence after being assured that after conviction he would be transferred to his country of nationality to serve his sentence, and that his country of nationality would be at liberty to convert the sentence in question. Where the transfer was made on condition that the country of nationality would continue with the enforcement of the sentence imposed in the sentencing country, it was held:

Turning to the circumstances of the present case, the Court observes that, from a technical point of view, the applicant's conviction became final on 16 September 2002 when he waived his right to appeal against the Lübeck Regional Court's judgment of that date. The Court considers, however, that under the particular circumstances of this case it has to be taken into account that the proceedings relating to the applicant's transfer request were very closely related to the criminal proceedings and to the final determination of the sentence. The Court notes, in particular, that the Public Prosecutor, during the proceedings leading to the applicant's conviction, expressly declared that they had no objections to the transfer of the applicant to the Netherlands. It was only in view of this reassurance that the applicant returned to Germany in order to stand trial and gave a full confession leading to his criminal conviction. Although the Lübeck Regional Court imposed a criminal sentence based on the applicant's conviction, this was not to be considered as final having regard to the possibility of converting the sentence following a transfer to the applicant's home country. Finally, the Court notes that according to the express statement of the Lübeck Regional Court the oral hearing - and consequently the applicant's conviction - would probably not have been possible without the applicant's cooperation. Having regard to these exceptionally close connections between the criminal proceedings and the proceedings concerning the applicant's transfer request, it would be too formalistic to limit the scope of application of Article 6 under its criminal head to the proceedings which took place before pronouncement of the judgment on 16 September 2002. The Court therefore considers that the transfer proceedings have to be regarded as an integral part of the criminal

146 It should be noted in passing that for offenders transferred under the Council of Europe's Convention on the Transfer of Sentenced Persons, for example, from Mauritius to the UK, the UK made a reservation at the time of ratifying the treaty that it will continue with the enforcement of the sentences imposed by the sentencing country unless such a sentence is higher than the maximum sentence that could be imposed under the UK law, in which case the sentence would be adapted to the maximum number of years to which an offender in the UK could be sentenced.Provided, of course, that such a move does not aggravate the sentence imposed by the sentencing country. See generally, Dirk van Zyl Smit and John. Spencer, The European Dimension to the Release of Sentenced Persons, in: Nicola Padfield, Dirk van Zyl Smit, Frieder Dünkel (eds.), Release from Prison: European Policy and Practice, New York2010 pp. 25 - 26.

147 Michael Abbell, International Prisoner Transfer, New York(2010). pp. 27 -30, pp. 110 - 111. 
proceedings in so far as they directly relate to the assurance which was given by the Public Prosecutor during the criminal proceedings. ${ }^{148}$

There is therefore a need for countries to make sure that the issue of continued enforcement and of conversion of the sentence in question is handled carefully in a manner that would not discourage sentencing countries from transferring offenders, and at the same time not discourage offenders from consenting to the transfer on the basis that if transferred they could spend more time in prison than if they had served their sentences in the sentencing country. This could be resolved by, for example, ensuring that offences under the Convention against Corruption attract more or less the same sentences in all countries so that there is no big difference whether the sentence is served in the sentencing country or in the administering country. However, the laws relating to the parole or early release of offenders could tip the scales in favour or against an offender, and this would most likely depend on his conduct in prison.

\section{People subject to transfer}

Article 45 of the Convention against Corruption stipulates that states parties may enter into bilateral or multilateral arrangements on the 'transfer to their territory of persons sentenced to imprisonment or other forms of deprivation of liberty...' Article 45 thus provides for two categories of offenders that could be transferred: those who have been sentenced to imprisonment and those who have been sentenced to other forms of deprivation of liberty. The meaning of 'imprisonment' is very clear. This begs the question of what amounts to deprivation of liberty. Rule 11(b) of the United Nations Rules for Protection of Juveniles Deprived of their Liberty provides that ' $[\mathrm{t}]$ he deprivation of liberty means any form of detention or imprisonment or the placement of a person in a public or private custodial setting, from which this person is not permitted to leave at will, by order of any judicial, administrative or other public authority. ${ }^{149}$ It should be recalled that Article 10(1) of the ICCPR provides that '[a]11 persons deprived of their liberty shall be treated with humanity and with respect for the inherent dignity of the human person', and that the Human Rights Committee in General Comment No. 21 has stated:

Article 10, paragraph 1, of the International Covenant on Civil and Political Rights applies to any one deprived of liberty under the laws and authority of the State who is held in prisons, hospitals - particularly psychiatric hospitals - detention camps or correctional institutions or elsewhere. States parties should ensure that the principle

148 Smith v Germany, Application no. 27801/05, judgement of 1 April 2010, paras $40-41$. See also Buijen v Germany, Application no. 27804/05, judgment of 1 April 2010 paras $41-42$.

149 United Nations Rules for Protection of Juveniles Deprived of their Liberty, Adopted by General Assembly Resolution 45/113 of 14 December 1990. 
stipulated therein is observed in all institutions and establishments within their jurisdiction where persons are being held. ${ }^{150}$

In the light of the above it is evident that Article 45 is applicable only to people who have been sentenced to custodial sentences. Although African countries are encouraging the use of non-custodial sentences in order to reduce the level of recidivism and to encourage rehabilitation and re-integration of offenders, ${ }^{151}$ the Convention does not permit them to transfer offenders who have been sentenced to forms of punishment that do not involve the deprivation of liberty. This is unfortunate as there is no evidence that imprisonment is the most appropriate form of punishment to deter people from committing offences. In the light of the poor prison conditions in Africa, it is unlikely that the majority of the offenders sentenced to imprisonment will be rehabilitated and eventually reintegrated into society. It is therefore recommended that countries, both in Africa and in other parts of the world, which have ratified the Convention against Corruption, should implement Article 45 so that they are able to transfer people sentenced to non-custodial sentences to serve their sentences in other countries since Article 45 does not expressly prohibit the transfer of offenders sentenced to non-custodial sentences. However, this would depend on the availability of suitable supervision mechanisms in the administering country.

The Convention allows a state party to transfer from its territory any person sentenced to imprisonment or any other form of deprivation of liberty to another state party to serve his sentence there. This is broad enough to include citizens, nationals, permanent residents or any person who in the view of the state party should serve the remainder of his sentence in the territory of that other state party. The drafting history of the Convention is not clear as to why the provision is broad enough to include any person that the state party thinks should serve the remainder of his sentence in the enforcement country. It is argued that in the African context, and indeed in the Inter-American ${ }^{152}$ and European ${ }^{153}$ regions, Article 45 is most likely

150 Human Rights Committee, General Comment No.21 (Replaces General Comment 9 concerning humane treatment of persons deprived of their liberty (Article 10): 4 October 1992, para 2.

151 See generally, Jamil Ddamulira Mujuzi, Alternative Sentencing under the African Human Rights Instruments and Mechanisms: Lessons for Southern Africa,University of Botswana Law 8 (2008), pp. 47 - 78. In its Concluding Observations on Angola's Second Period Report (May 2012), the African Commission on Human and Peoples' Rights recommended that Angola should '[t]ake all necessary measures to reduce overcrowding in prisons, such as adopting alternative sentencing policies and imposing non-custodial sentences such as community service.' See http://www.achp r.org/states/angola/reports/2nd-1999-2010/ (last acecssed on 23 November 2013).

152 Article III(4) of the Inter-American Convention on Serving Criminal Sentences Abroad, provides, inter alia, that for the Convention to be applicable, '[t]he sentenced person must be a national of the receiving state.'.

153 Article 3(1)(a) of the Council of Europe's Convention on Transfer of Sentenced Persons provides that a sentenced person can only be transferred under the Convention, if, inter alia, 'that person is a national of the administering state.' In Catenacci v. Canada (Attorney General) 2006 CarswellNat 1364, 2006 FC 539, 144 C.R.R. (2 d) 128, 291 F.T.R. 215, the applicant was an Italian citizen but a permanent resident in Canada and had lived in Canada since he was two years old. His parents, 
to be applicable to the transfer of nationals, citizens or persons with close ties to the country enforcing the sentence. Legislation or a bilateral arrangement on the transfer of offenders in Africa requires that for an offender to be transferred, he has either to be a national or citizen $^{154}$ of the administering state or have close ties with it. ${ }^{155}$ Furthermore, Article 30(10) provides that 'States Parties shall endeavour to promote the reintegration into society of persons convicted of offences established in accordance with this Convention.' It is easier for one to re-integrate in a country of which he is a citizen or with which he has close ties. Therefore, Article 45 should be understood as mostly being applicable to nationals or citizens of, or people with close ties with, the administering country. One also has to note that in Africa the transfer of offenders can only take place with the consent of both the sentencing and the administering states. Therefore, the administering country would have to motivate to the satisfaction of the sentencing country why a person who is not its citizen, national or one having close ties with it should be transferred to serve his sentence within its territory.

\section{Costs of the transfer}

The transfer of an offender from the sentencing to the administering country involves costs. Costs are incurred from the moment the offender leaves the prison or detention facility of the sentencing state until he is put into the custody of the administering state. The question is thus: who pays that bill? Different approaches and arrangements have been adopted. Both the

children and wife were Canadian citizens. He was convicted of drug-related offences in the USA and applied to be transferred to serve his sentence in Canada. In rejecting his application for the transfer, the Federal Court held that 'Canada has, by both treaty and domestic legislation, defined "national" as a Canadian citizen. Most states do likewise. However, under the Council of Europe, Convention on Transfer of Sentenced Persons, any state which is a member of the Council can determine who is a "national" - four states have included permanent residents as nationals. Likewise, in the Commonwealth Scheme for the Transfer of Offenders, a national can include a person who has "close ties with the administering country of a kind that may be recognized by that country for purposes of this Scheme". Some countries have recognized permanent residents as nationals.' See para 25.

154 Section 2(b) of the Namibian Transfer of Convicted Offenders Act (provides that such a person has to be a national or citizen of Namibia); section 3 of the Tanzania Transfer of Prisoners Act (only a citizen can be transferred); section 4(a) of the Ghanian Transfer of Convicted Persons Act; section 5(1)(a) of the Nigerian Transfer of Convicted Offenders (Enactment and Enforcement) Act; Article 3(a) of the Agreement between UK and Uganda is applicable to only nationals of Uganda and national is interpreted to mean citizen under Article 1; Article 3(a) of the Agreement between UK and Rwanda (refers to national); Article 4(b) of the Agreement between UK and Morocco (refers to national); and Article 4(1) of the Agreement between UK and Egypt.

155 See, for example, section 2 of the Zambian Transfer of Convicted Persons Act; section 2(1) of the Mauritian Transfer of Prisoner Act; section 2(1) of the Zimbabwean Transfer of Offenders Act (is applicable to a citizen, permanent resident or person with close ties); section 2(1) of the Malawian Transfer of Offenders Act No. 25 of 1991; section 5(1)(a) of the Swazi Transfer of Convicted Offenders Act; section 4 of the Ugandan Transfer of Convicted Offenders Act; Article 3(a) of the Agreement between UK and Libya; Article 3(a) of the Agreement between UK and Ghana. 
Namibian ${ }^{156}$ and Ugandan ${ }^{157}$ legislation provides that the costs of the transfer shall either be borne by the transferring state or the receiving state or shall be shared between them. The Zambian legislation provides that the costs of the transfer shall be borne by both the receiving and the transferring states. ${ }^{158}$ Like the Zambian legislation, the Nigerian, ${ }^{159}$ Swaziland, ${ }^{160}$ and Ghanaian ${ }^{161}$ pieces of legislation also provide that the costs of the transfer shall be borne by both the sentencing country and the administering country in such proportions as they may agree. However, the Tanzanian ${ }^{162}$ and the Mauritian ${ }^{163}$ transfer of offenders legislation provides that there are circumstances where an offender who has applied to be transferred to serve his sentence in Tanzania or Mauritius should be responsible for the transfer costs. An arrangement involving the possibility of the transferred person paying the transfer costs or part thereof could raise some difficult questions. For example, what would happen where the offender has consented to the transfer and both countries have agreed that the transfer should take place but the offender refuses to incur the costs of the transfer even if he has the means to pay them? Would the transfer not take place even if the sentencing and administering states both have the means to pay for the transfer and are of the view that it is in the offender's best interest that the transfer should take place?

\section{Conclusion}

The need to transfer persons to serve their sentences or part of their sentences has, for many years, been recognised by the United Nations and by countries throughout the world. Many African countries have legislation or have entered into bilateral arrangements to transfer offenders to African countries or to countries outside Africa. The UN Convention against Corruption, which has been ratified or acceded to by many African countries, provides in Article 45 that states parties may enter into bilateral or multilateral arrangements for the transfer of persons convicted of offences under the convention. This article has compared the relevant provisions of the UN Convention against Corruption with those of the African Union Convention on Corruption and has dealt with the drafting history of Article 45 and the prospects and challenges that are likely to impact on its implementation in Africa. The author has focused on the following issues: the available options for African countries to implement Article 45; the role of the courts in the transfer of offenders; the consent of the offender to the transfer; the issue of human rights in the context of the transfer; the sentences that could be imposed 
and whether there should be continued enforcement or conversion thereof in the case of a transfer; the people subject to the transfer; and the costs of the transfer. It is recommended that African countries should explore the possibility of drafting and adopting a prisoner transfer treaty which should be the benchmark against which prisoner transfer legislation and arrangements in Africa should be modelled. 